\title{
REACTIONS OF TITANOCENE- AND ZIRCONOCENE- BIS(TRIMETHYLSILYL)ACETYLENE COMPLEXES WITH SELECTED HETEROCYCLIC AND AROMATIC NH AND OH ACID COMPOUNDS
}

\author{
Perdita ARNDT ${ }^{a 1, *}$, Vladimir V. BURLAKOV ${ }^{b}$, Ulrike JÄGER-FIEDLER ${ }^{a}$, \\ Marcus KLAHN ${ }^{a 2}$, Anke SPANNENBERG ${ }^{a 3}$, Wolfgang BAUMANN ${ }^{a 4}$ and \\ Uwe ROSENTHAL ${ }^{a 5, *}$ \\ ${ }^{a}$ Leibniz-Institut für Katalyse e. V. an der Universität Rostock, Albert-Einstein-Str. 29a, \\ D-18059 Rostock, Germany; e-mail: ${ }^{1}$ perdita.arndt@catalysis.de, ${ }^{2}$ marcus.klahn@catalysis.de, \\ 3 anke.spannenberg@catalysis.de, ${ }^{4}$ wolfgang.baumann@catalysis.de, ${ }^{5}$ uwe.rosenthal@catalysis.de \\ ${ }^{b}$ A. N. Nesmeyanov Institute of Organoelement Compounds, Russian Academy of Sciences, \\ Vavilov St. 28, 117813 Moscow, Russia; e-mail:vvburl@mail.ru
}

Received January 19, 2007

Accepted March 1, 2007

Dedicated to Dr Karel Mach on the occasion of his 70th birthday in recognition of his outstanding contributions to the area of organometallic synthesis and catalysis.

The titanocene complexes $\mathrm{Cp}_{2}^{\prime}{ }_{2} \mathrm{Ti}\left(\eta^{2}-\mathrm{Me}_{3} \mathrm{SiC}_{2} \mathrm{SiMe}_{3}\right)\left(\mathrm{Cp^{ \prime }}=\mathrm{Cp}(\mathbf{1}), \mathrm{Cp} *(\mathbf{2})\right)$ react with pyrrole under the formation of the titanium(III) mono-N-pyrrolides $\mathrm{Cp}_{2}^{\prime}{ }_{2}^{\mathrm{Ti}}\left(\mathrm{NC}_{4} \mathrm{H}_{4}\right)\left(\mathrm{Cp}^{\prime}=\mathrm{Cp}(6)\right.$, $\mathrm{Cp} *$ (7)); whereas the corresponding zirconocene system $\mathrm{Cp}_{2} \mathrm{Zr}\left(\eta^{2}-\mathrm{Me}_{3} \mathrm{SiC}_{2} \mathrm{SiMe}_{3}\right)$ (thf) (3) forms in a different reaction pathway first the $\mathrm{Cp}_{2} \mathrm{Zr}\left(\mathrm{NC}_{4} \mathrm{H}_{4}\right)\left[\mathrm{C}\left(\mathrm{SiMe}_{3}\right)=\mathrm{CH}\left(\mathrm{SiMe}_{3}\right)\right](\mathbf{8})$ and then the zirconium(IV) bis- $\mathrm{N}$-pyrrolide $\mathrm{Cp}_{2} \mathrm{Zr}\left(\mathrm{NC}_{4} \mathrm{H}_{4}\right)_{2}$ (11). With $\mathrm{Cp}_{2}{ }_{2} \mathrm{Zr}\left(\eta^{2}-\mathrm{Me}_{3} \mathrm{SiC}_{2} \mathrm{SiMe}_{3}\right)$ (4) and pyrrole, the zirconium(IV) mono- $\mathrm{N}$-pyrrolide with an agostic alkenyl group $\mathrm{Cp}_{2}{ }_{2} \mathrm{Zr}\left(\mathrm{NC}_{4} \mathrm{H}_{4}\right)\left[\mathrm{C}\left(\mathrm{SiMe}_{3}\right)=\mathrm{CH}\left(\mathrm{SiMe}_{3}\right)\right]$ (9) was obtained. In the reaction of the ethylenebistetrahydroindenyl (ebthi) complex rac-(ebthi) $\mathrm{Zr}\left(\eta^{2}-\mathrm{Me}_{3} \mathrm{SiC}_{2} \mathrm{SiMe}_{3}\right.$ ) (5) with 2,3,5,6-tetrafluoroaniline under $\mathrm{N}-\mathrm{H}$ bond activation, a complex with an agostic alkenyl group rac-(ebthi) $\mathrm{Zr}\left(\mathrm{NH}-\mathrm{C}_{6} \mathrm{HF}_{4}\right)\left[\mathrm{C}\left(\mathrm{SiMe}_{3}\right)=\mathrm{CH}\left(\mathrm{SiMe}_{3}\right)\right]$ (10) was formed. Compound $\mathbf{1 0}$ reacts with additional 2,3,5,6-tetrafluoroaniline to give the bisanilide rac-(ebthi) $\mathrm{Zr}\left(\mathrm{NH}-\mathrm{C}_{6} \mathrm{HF}_{4}\right)_{2}$ (12) which was obtained directly from $\mathbf{5}$ with two equivalents of 2,3,5,6-tetrafluoroaniline. In reactions of complex 5 with unsubstituted aniline to rac-(ebthi) $\mathrm{Zr}\left(\mathrm{NH}-\mathrm{C}_{6} \mathrm{H}_{5}\right)_{2}(\mathbf{1 3})$ and with pentafluorophenol to bisphenolate rac-(ebthi) $\mathrm{Zr}\left(\mathrm{O}-\mathrm{C}_{6} \mathrm{~F}_{5}\right)_{2}$ (14), no intermediates could be isolated. The new reaction products $\mathbf{6}, \mathbf{9}, \mathbf{1 0}, \mathbf{1 2}, \mathbf{1 3}$ and $\mathbf{1 4}$ were investigated by $\mathrm{X}$-ray crystallography.

Keywords: Metallocenes; Titanocenes; Zirconocenes; Organometallics; Heterocycles; Aromatics. 
In reactions of different titanocene and zirconocene complexes of bis(trimethylsilyl)acetylene $\mathrm{Cp}_{2} \mathrm{M}(\mathrm{L})\left(\eta^{2}-\mathrm{Me}_{3} \mathrm{SiC}_{2} \mathrm{SiMe}_{3}\right)(\mathrm{M}=\mathrm{Ti}, \mathrm{L}=\mathrm{nil}(\mathbf{1})$; $M=Z r, L=T H F(3)$ ), and the pentamethylcyclopentadienyl complexes $\mathrm{Cp}_{2}{ }_{2} \mathrm{M}\left(\eta^{2}-\mathrm{Me}_{3} \mathrm{SiC}_{2} \mathrm{SiMe}_{3}\right)(\mathrm{M}=\mathrm{Ti}$ (2), $\mathrm{Zr}(\mathbf{4})$ ) or the rac-ethylenebistetrahydroindenyl (ebthi) complex rac-(ebthi)M ( $\left.\eta^{2}-\mathrm{Me}_{3} \mathrm{SiC}_{2} \mathrm{SiMe}_{3}\right)(\mathrm{M}=\mathrm{Zr}(\mathbf{5})$ ), activation of several bonds was described in some reviews ${ }^{1-10}$. For example, cleavage of $\mathrm{C}-\mathrm{H}, \mathrm{C}-\mathrm{C}$ (Cp-ring opening, cleavage of butadiynes), $\mathrm{Si}-\mathrm{C}, \mathrm{P}-\mathrm{C}$, $\mathrm{N}-\mathrm{H}, \mathrm{N}-\mathrm{C}, \mathrm{N}-\mathrm{N}, \mathrm{Si}-\mathrm{O}, \mathrm{N}-\mathrm{O}, \mathrm{C}-\mathrm{O}, \mathrm{C}-\mathrm{S}, \mathrm{C}-\mathrm{F}$ and $\mathrm{C}-\mathrm{B}$ bonds gave complexes of potential applicability in stoichiometric and catalytic reactions.

Beckhaus and coworkers published very recently a series of excellent examples for reactions of titanocene-bis(trimethylsilyl)acetylene complexes with different $\mathrm{N}$-heterocyclic compounds ${ }^{11-15}$. In these reactions the complexes $\mathrm{Cp}_{2} \mathrm{Ti}\left(\eta^{2}-\mathrm{Me}_{3} \mathrm{SiC}_{2} \mathrm{SiMe}_{3}\right)$ and $\mathrm{Cp}_{2}{ }_{2} \mathrm{Ti}\left(\eta^{2}-\mathrm{Me}_{3} \mathrm{SiC}_{2} \mathrm{SiMe}_{3}\right)$ act, after dissociation of the alkyne, as sources of titanocene $\mathrm{Cp}_{2} \mathrm{Ti}$ and permethyltitanocene $\mathrm{Cp}_{2}{ }_{2} \mathrm{Ti}$, which dimerize and trimerize heterocycles to exciting compounds, e.g., with a cyclohexane or benzene core.

In this work we tried to extend such investigations about reactions of titanocene- and zirconocene-bis(trimethylsilyl)acetylene complexes to selected heterocyclic and aromatic $\mathrm{NH}$ and $\mathrm{OH}$ acidic compounds to find out differences in the behavior between the bis(trimethylsilyl)acetylene complexes of $\mathrm{Ti}$ and $\mathrm{Zr}$.

Several metallocene amido complexes $C p^{\prime}{ }_{2} M\left(N R R^{\prime}\right)_{2}\left(M=Z r: C p^{\prime}=C p=\right.$ $\eta^{5}-\mathrm{C}_{5} \mathrm{H}_{5}, \mathrm{R}=\mathrm{H}, \mathrm{R}^{\prime}=\mathrm{t}-\mathrm{Bu}, \mathrm{C}_{6} \mathrm{H}_{4}-\mathrm{t}-\mathrm{Bu}, 2,6-\mathrm{Me}_{2} \mathrm{C}_{6} \mathrm{H}_{3}, \mathrm{NRR}^{\prime}=\mathrm{NC}_{4} \mathrm{H}_{4}, \mathrm{Cp}_{2}^{\prime}=$ rac-(ebthi), $\mathrm{R}=\mathrm{H}, \mathrm{R}^{\prime}=2,6-\mathrm{MeC}_{6} \mathrm{H}_{3}, \mathrm{C}_{6} \mathrm{H}_{5}, \mathrm{C}_{6} \mathrm{~F}_{5}{ }^{16-19} ; \mathrm{M}=\mathrm{Ti}: \mathrm{Cp}^{\prime}=\mathrm{Cp}=$ $\left.\eta^{5}-\mathrm{C}_{5} \mathrm{H}_{5}, \mathrm{NRR}^{\prime}=\mathrm{NC}_{4} \mathrm{H}_{4}{ }^{19}, \mathrm{Cp}_{2}^{\prime}=\left[\mathrm{Me}_{2} \mathrm{Si}\left(\mathrm{C}_{5} \mathrm{Me}_{4}\right)_{2}\right], \mathrm{NRR}^{\prime}=\mathrm{NC}_{4} \mathrm{H}_{4}\right)^{20}$ were synthesized starting from $\mathrm{Cp}_{2} \mathrm{MX}_{2}(\mathrm{X}=\mathrm{Cl}, \mathrm{Br})$ and an alkali $(\mathrm{Na}, \mathrm{Li})$ amide or by heating of $\mathrm{Cp}_{2} \mathrm{MMe}_{2}(\mathrm{M}=\mathrm{Zr}$, Ti) in the presence of the corresponding amine in THF. Also the Ti(III) amide complex $\mathrm{Cp}_{2}{ }_{2} \mathrm{Ti}(\mathrm{NM} \mathrm{ePh})$ was obtained by the reaction of $\mathrm{Cp}_{2}{ }_{2} \mathrm{TiX}$ with lithium amide ${ }^{21}$.

In 1988 Bergman et al. ${ }^{17,22}$ found that complexes $\mathrm{Cp}_{2} \mathrm{Zr}(\mathrm{NHR})_{2}$ eliminate 1 equivalent of $\mathrm{RNH}_{2}$ (by heating) giving very reactive zirconocene imido derivatives $C p_{2} Z r=N R$ which show an extensive reaction chemistry. For example, $[2+2]$ cycloadditions with alkynes led to azametallacyclobutenes which gave (after protonation and reaction with an additional amine) enamines and regenerated the starting zirconocene bisamide complexes. Based on this investigations, Bergman et al. developed a hydroamination of alkynes with zirconocene bisamides $\mathrm{Cp}_{2} \mathrm{Zr}(\mathrm{NHR})_{2}$ as catalysts ${ }^{17}$.

Related hydroamination processes were reported with catalysts such as

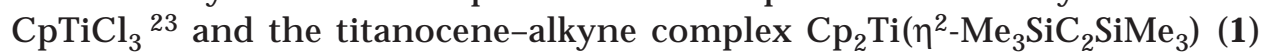
used by Beller et al. ${ }^{24}$. 
We investigated and compared titanocene- and zirconocene-alkyne complexes $C p_{2}^{\prime} \mathrm{M}(\mathrm{L})\left(\eta^{2}-\mathrm{Me}_{3} \mathrm{SiC}_{2} \mathrm{SiMe}_{3}\right)\left(\mathrm{M}=\mathrm{Ti}: \mathrm{L}=\mathrm{nil}, \mathrm{Cp}_{2}^{\prime}=\mathrm{Cp}_{2}=\left(\eta^{5}-\mathrm{C}_{5} \mathrm{H}_{5}\right)_{2}\right.$ (1), $\mathrm{Cp}_{2}{ }_{2}=\left(\eta^{5}-\mathrm{C}_{5} \mathrm{Me}_{5}\right)_{2}$ (2); $\mathrm{M}=\mathrm{Zr}: \mathrm{L}=\mathrm{THF}, \mathrm{Cp}_{2}^{\prime}=\mathrm{Cp}_{2}$ (3), Cp*2 (4), rac-(ebthi $)=5)$ in their reactions with amines like anilines $\left(\mathrm{H}_{2} \mathrm{~N}-\mathrm{C}_{6} \mathrm{H}_{5}\right.$ and $\left.\mathrm{H}_{2} \mathrm{~N}-\mathrm{C}_{6} \mathrm{HF}_{4}\right)$ and their aromatic cyclic counterpart pyrrole $\left(\mathrm{HNC}_{4} \mathrm{H}_{4}\right)$.

\section{RESULTS AND DISCUSSION}

Reactions of titanocene complexes $\mathrm{Cp}_{2}^{\prime}{ }_{2} \mathrm{Ti}\left(\eta^{2}-\mathrm{Me}_{3} \mathrm{SiC}_{2} \mathrm{SiMe}_{3}\right)$ with nitrogen bases like aldimines and ketimines ${ }^{25 a}$, oxazoles, isoxazoles, thiazol es ${ }^{25 b}$ and siloximes ${ }^{25 c}$ were detailed investigated and give Ti(IV) products of oxidative addition and a release of the acetylene $\mathrm{Me}_{3} \mathrm{SiC} \equiv \mathrm{CSiMe_{3 }}$. On the other hand, with 2,2'-bipyridyl and 4,5-diazafluorene, an electron transfer from a titanocene species gives $\mathrm{Ti}(\mathrm{III})$ compounds with a bipyridyl radical anion and under separation of hydrogen a diazafluorenyltitanocene complex ${ }^{26}$. $\mathrm{Cp}_{2}{ }_{2} \mathrm{Ti}\left(\eta^{2}-\mathrm{Me}_{3} \mathrm{SiC}_{2} \mathrm{SiMe}_{3}\right.$ ) (2) gives with $\mathrm{Me}_{2} \mathrm{C}=\mathrm{N}-\mathrm{N}=\mathrm{CMe}_{2}$ reconducted by the splitting of the acetone azine also a Ti(III) complex $\left(\eta^{5}-\mathrm{C}_{5} \mathrm{Me}_{5}\right)_{2} \mathrm{Ti}\left(\mathrm{N}=\mathrm{CMe}_{2}\right)^{27}$.

We report here, that the titanocene complexes $\mathrm{Cp}_{2} \mathrm{Ti}\left(\eta^{2}-\mathrm{Me}_{3} \mathrm{SiC}_{2} \mathrm{SiMe}_{3}\right)$ (1) and $\mathrm{Cp}_{2}{ }_{2} \mathrm{Ti}\left(\eta^{2}-\mathrm{Me}_{3} \mathrm{SiC}_{2} \mathrm{SiMe}_{3}\right)$ (2) react with pyrrole under gas (probably hydrogen) evolution and formation of paramagnetic $\mathrm{Ti}(\mathrm{III})$ mono-Npyrrolides 6 and $7^{28}$ (Scheme 1).

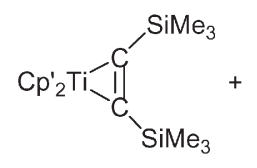

$C p^{\prime}=\underset{C p}{C p^{*}(2)}$
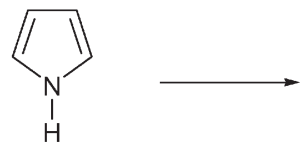

\section{SCHEME 1}

Reactions of the corresponding zirconocene-bis(trimethylsilyl)acetylene complexes $\mathbf{3}$ and $\mathbf{4}$ with pyrrole followed another pathway. Upon $\mathrm{N}-\mathrm{H}$ activation and without alkyne elimination, the formation of the alkenyl complexes $\mathbf{8}$ and $\mathbf{9}$ with an agostic interaction was observed in a first step (Scheme 2).

When complex $\mathbf{8}$ is heated or treated with an equimolar amount of pyrrole, the alkenyl group gets lost and a bispyrrolide-zirconocene complex $\mathbf{1 1}$ is formed (Scheme 2). This bisamide $\mathbf{1 1}$ was described before as the product of the reaction of a zirconocene dihalogenide with 2 equivalents of alkali pyrrolide ${ }^{16,19}$. NMR investigations of the conversion of 8 in solution $\left(C_{6} D_{6}\right.$, $50{ }^{\circ} \mathrm{C}$ ) demonstrate that, besides the bisamide 11, also free bis(trimethyl- 
silyl)acetylene and further silyl species are obtained (there is good evidence for the generation of $(\mathrm{E})-\mathrm{Me}_{3} \mathrm{SiCH}=\mathrm{CHSiMe}$, but neither this nor a formal hydroamination product like $\mathrm{C}_{4} \mathrm{H}_{4} \mathrm{~N}-\mathrm{C}\left(\mathrm{SiMe}_{3}\right)=\mathrm{CH}\left(\mathrm{SiMe}_{3}\right)$ were proven). With $\mathrm{Cp}_{2}{ }_{2} \mathrm{Zr}\left(\eta^{2}-\mathrm{Me}_{3} \mathrm{SiC}_{2} \mathrm{Si} \mathrm{Me}_{3}\right)$ (4) and pyrrole, under the same conditions, only the mono-N-pyrrolide with an agostic alkenyl group (9) was obtained.

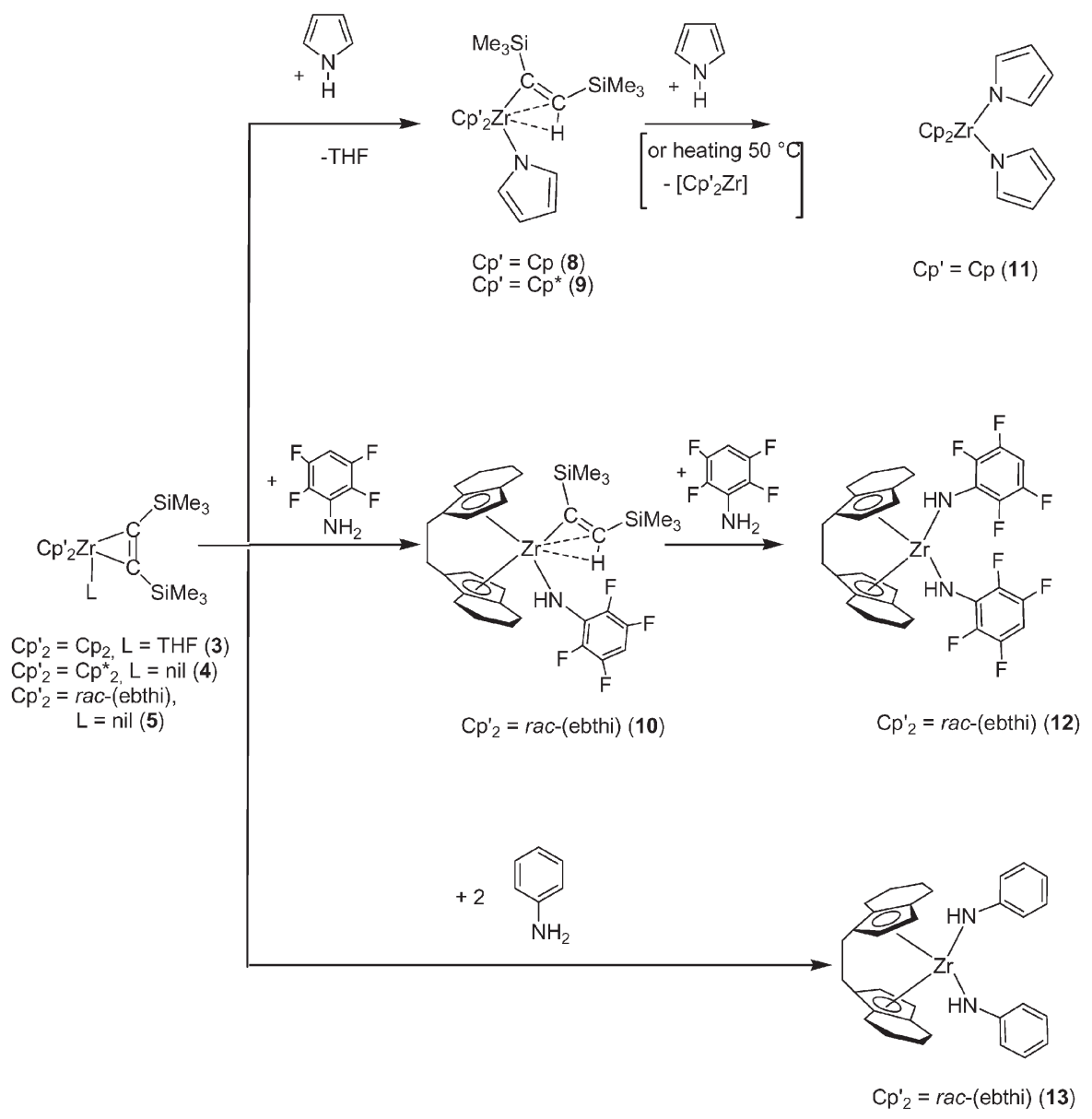

\section{SCHEME 2}

In the reaction of the ethylenebistetrahydroindenyl complex rac-(ebthi) Zr $\left(\eta^{2}-\mathrm{Me}_{3} \mathrm{SiC}_{2} \mathrm{SiMe}_{3}\right.$ ) (5) with 2,3,5,6-tetrafluoroaniline under $\mathrm{N}-\mathrm{H}$ bond activation, the complex with an agostic alkenyl group rac-(ebthi) $\mathrm{Zr}\left(\mathrm{NH}-\mathrm{C}_{6} \mathrm{HF}_{4}\right)\left[\mathrm{C}\left(\mathrm{SiMe}_{3}\right)=\mathrm{CH}\left(\mathrm{SiMe}_{3}\right)\right]$ (10) was formed. Compound $\mathbf{1 0}$ reacts with an excess 2,3,5,6-tetrafluoroaniline to the bisanilide 
rac-(ebthi) $\mathrm{Zr}\left(\mathrm{NH}-\mathrm{C}_{6} \mathrm{HF}_{4}\right)_{2}$ (12) which was also obtained directly from $\mathbf{5}$ with two equivalents of 2,3,5,6-tetrafluoroaniline (Scheme 2).

Complex 5 reacted with unsubstituted aniline to give the bisamide rac-(ebthi) $\mathrm{Zr}\left(\mathrm{NH}-\mathrm{C}_{6} \mathrm{H}_{5}\right)_{2}$ (13); in contrast to 2,3,5,6-tetrafluoroaniline, no alkenyl complex as intermediate could be isolated.

In the same manner, in the reaction of $\mathbf{5}$ with pentafluorophenol, the alkyne was eliminated and the corresponding rac-(ebthi) $\mathrm{Zr}\left(\mathrm{O}-\mathrm{C}_{6} \mathrm{~F}_{5}\right)_{2}$ (14) was formed (Scheme 3).

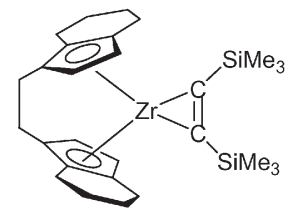

5
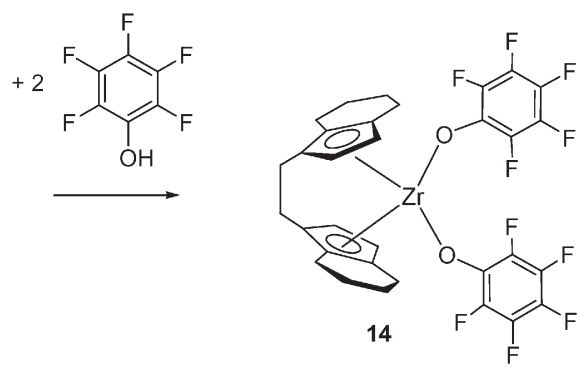

SCHEME 3

A similar bis(pentafluorophenolate) complex was described for the $\mathrm{Cp}$-zirconocene system $\mathrm{Cp}_{2} \mathrm{Zr}\left(\mathrm{O}-\mathrm{C}_{6} \mathrm{~F}_{5}\right)_{2}{ }^{29}$.

\section{NMR and Molecular Structure Data}

The most characteristic NMR and molecular structural feature of the alkenyl compounds $\mathbf{8}, \mathbf{9}$ and $\mathbf{1 0}$ is the agostic interaction of the alkenyl group with zirconium $\mathrm{Zr}-\mathrm{C}^{\alpha}=\mathrm{C}^{\beta}-\mathrm{H}$. These alkenyl units show ${ }^{1} \mathrm{H}$ NMR signals at rather low fields (8: 8.04, 9: 6.67, 10: 7.20 ppm) and the ${ }^{13} \mathrm{C} \mathrm{NMR}$ signals of $C^{\alpha}$ appear always downfield, but those for $C^{\beta}$ in most cases slightly upfield compared with the normal olefin range. Typical of the additional agostic interaction is the especially small coupling constant ${ }^{1} \mathrm{~J}\left(\mathrm{C}^{\beta}-\mathrm{H}\right)$ (8: 100, 9: 101, $10105 \mathrm{~Hz}$ ). In the molecular structure, acute $\mathrm{Zr}-\mathrm{C}^{\alpha}-\mathrm{C}^{\beta}$ angles and short $\mathrm{Zr}-\mathrm{C}^{\beta}$ bond lengths reflect this special type of interaction. All these features were found before in selected similar complexes such as: $\left[\mathrm{CpZr}\left(\mu-\eta^{1}: \eta^{5}-\mathrm{C}_{5} \mathrm{H}_{4}\right)\left(\mathrm{C}\left(\mathrm{SiMe}_{3}\right)=\mathrm{CH}\left(\mathrm{Si} \mathrm{Me}_{3}\right)\right]_{2}\right.$

$(\mathbf{A})^{30}$, $\left[\mathrm{Cp}_{2}{ }_{2} \mathrm{Zr}\left(\mathrm{C}\left(\mathrm{CCM} \mathrm{e}_{3}\right)\left(\mathrm{C}\left(\mathrm{SiMe}_{3}\right)=\mathrm{CH}\left(\mathrm{SiMe}_{3}\right)\right](\mathbf{B})^{31}\right.\right.$ and the propane-3-lactamate $\left[\mathrm{Cp}_{2} \mathrm{Zr}\left(\mathrm{NC}_{3} \mathrm{H}_{4} \mathrm{O}\right)\left(\mathrm{C}\left(\mathrm{SiMe}_{3}\right)=\mathrm{CH}\left(\mathrm{SiMe}_{3}\right)\right](\mathbf{C})^{32}\right.$, which are all typical examples of zirconocene $\sigma$-alkenyl complexes with agostic $\mathrm{C}^{\beta}-\mathrm{H} \cdots \mathrm{Zr}$ interactions (Table I). 
In the ${ }^{19} \mathrm{~F}$ NMR spectra of complex 10, the chemical shifts on the fluorine substitutents at the aromatic ring are in the region of uncoordinated fluoroaromatics (ca. $-150 \mathrm{ppm}$ ) and not shifted to an extremely high field, as found for fluoro-bridged $\mathrm{Zr}-\mathrm{F}-\mathrm{C}$ groups (ca. $-200 \mathrm{ppm})^{33}$. Differences show up for the proton signal of the agostic $\mathrm{CH}$ group: it appears as singlet for $\mathbf{8}$ or $\mathbf{9}$, but as triplet for $\mathbf{1 0}$ (coupling to two fluorine atoms, made equivalent by phenyl rotation). The steric demand of the rac-ebthi ligand system seems to force alkenyl and phenyl group close together, and hence spin-spin coupling through space becomes operative. Further steric effects are evident from a comparison of complex $\mathbf{9}$ (with the Cp* ligand) to the $\mathrm{Cp}$ complex 8: only one signal for each pair of pyrrolide $\alpha$ - and $\beta-\mathrm{CH}$ groups appears for the latter, but four nonequivalent groups are observed for the former (broad signals at room temperature which coalesce pairwise at about $35^{\circ} \mathrm{C}$; see Experimental) and indicate that the rotation around the $\mathrm{N}-\mathrm{Zr}$ bond is hindered for $\mathbf{9}$.

\section{TABLE I}

Comparison of spectroscopic and structural data of complexes with agostic interactions $\left[\mathrm{Cp}_{2}^{\prime} \mathrm{Zr}(\mathrm{R})\left\{\left(\mathrm{C}^{\alpha}\left(\mathrm{SiMe}_{3}\right)=\mathrm{C}^{\beta}-\mathrm{H}\left(\mathrm{SiMe}_{3}\right)\right\}\right]\right.$

\begin{tabular}{|c|c|c|c|c|c|c|}
\hline Compounds & 8 & 9 & 10 & A & B & C \\
\hline $\begin{array}{l}\mathrm{Cp}_{2}^{\prime} \\
\mathrm{R}\end{array}$ & $\begin{array}{l}\mathrm{Cp}_{2} \\
\mathrm{NC}_{4} \mathrm{H}_{4}\end{array}$ & $\begin{array}{l}\mathrm{Cp}_{2} \\
\mathrm{NC}_{4} \mathrm{H}_{4}\end{array}$ & $\begin{array}{l}\text { ebthi } \\
\mathrm{HN}-\mathrm{C}_{6} \mathrm{HF}_{4}\end{array}$ & $\begin{array}{l}\mathrm{Cp} \\
\left(\mu-\eta^{1}: \eta^{5}-\mathrm{C}_{5} \mathrm{H}_{4}\right)^{30}\end{array}$ & $\begin{array}{l}\mathrm{Cp}_{2} \\
\mathrm{C} \equiv \mathrm{CCM} \mathrm{e}_{3}{ }^{31}\end{array}$ & $\begin{array}{l}\mathrm{Cp}_{2} \\
\mathrm{NC}_{3} \mathrm{H}_{4} \mathrm{O}^{32}\end{array}$ \\
\hline
\end{tabular}

\begin{tabular}{|c|c|c|c|c|c|c|}
\hline$\delta\left(C^{\beta}-H\right)$ & 8.04 & 6.67 & 7.20 & $7.52 / 7.28$ & 7.04 & 8.04 \\
\hline \multicolumn{7}{|l|}{${ }^{13} \mathrm{C} N \mathrm{NMR}$} \\
\hline$\delta\left(C^{\alpha}\right)$ & 232.9 & 230.6 & 227.0 & $230.2 / 230.3$ & 223.7 & 227.0 \\
\hline$\delta\left(C^{\beta}\right)$ & 105.4 & 112.8 & 123.1 & $101.7 / 100.4$ & 111.3 & 106.3 \\
\hline${ }^{1} \mathrm{~J}\left(\mathrm{C}^{\beta}-\mathrm{H}\right), \mathrm{Hz}$ & 100 & 101 & 105 & $97 / 96$ & 95 & 101 \\
\hline \multicolumn{7}{|c|}{ Bond length, Å } \\
\hline$d\left(Z r-C^{\alpha}\right)$ & & $2.296(3)$ & $2.271(3)$ & $2.244(3)$ & $2.298(2)$ & $2.242(3)$ \\
\hline$d\left(Z r-C^{\beta}\right)$ & & $2.570(3)$ & $2.591(3)$ & $2.566(3)$ & $2.534(2)$ & $2.543(3)$ \\
\hline$d\left(C^{\alpha}=C^{\beta}\right)$ & & $1.327(4)$ & $1.326(4)$ & $1.318(5)$ & $1.340(4)$ & $1.330(4)$ \\
\hline$d(Z r-N)$ & & $2.297(2)$ & $2.238(3)$ & & & $2.238(3)$ \\
\hline \multicolumn{7}{|l|}{ Angle, ${ }^{\circ}$} \\
\hline$Z r-C^{\alpha}-C^{\beta}$ & & $85.97(19)$ & $88.1(2)$ & $88.2(2)$ & 83.9(1) & $86.9(2)$ \\
\hline
\end{tabular}


The bisamide complexes 11, 12 and $\mathbf{1 3}$ as well as the bisphenolate $\mathbf{1 4}$ exhibit in the NMR spectra, besides the resonances of the Cp or ebthi ligand system, only one set of signals of aromatic rings, which indicates that the arylamido and aryloxo ligands, respectively, are equivalent.

The complexes $\mathbf{6}, \mathbf{9}, \mathbf{1 0}, \mathbf{1 2}, \mathbf{1 3}$ and $\mathbf{1 4}$ were investigated by $X$-ray crystallography; they display the general feature of bent metallocenes. The crystallographic data are presented in Table II and the molecular structures are depicted in Figs 1-6.

TABLE II

Crystallographic data (compounds 6, 9, 10, 12, 13, and 14)

\begin{tabular}{|c|c|c|c|c|c|c|}
\hline Parameter & 6 & 9 & 10 & 12 & 13 & 14 \\
\hline Crystal system & orthorhombic & monoclinic & monoclinic & monoclinic & monoclinic & monoclinic \\
\hline Space group & $\mathrm{P} 2_{1} 2_{1} 2_{1}$ & $\mathrm{P} 2_{1} / \mathrm{c}$ & $\mathrm{P} 2_{1} / \mathrm{C}$ & $\mathrm{P} 2_{1} / \mathrm{C}$ & $\mathrm{C} 2 / \mathrm{c}$ & $\mathrm{C} 2 / \mathrm{C}$ \\
\hline $\mathrm{a}, \AA$ & $7.885(2)$ & $19.505(4)$ & $14.616(3)$ & $8.894(2)$ & $12.759(3)$ & $17.501(4)$ \\
\hline$b, \AA$ & $9.526(2)$ & $9.969(2)$ & $12.404(2)$ & $34.307(7)$ & $14.361(3)$ & $10.212(2)$ \\
\hline$c, \AA$ & $15.323(3)$ & $18.469(4)$ & $19.515(4)$ & $9.385(2)$ & $13.776(3)$ & $15.592(3)$ \\
\hline$\alpha,{ }^{\circ}$ & 90 & 90 & 90 & 90 & 90 & 90 \\
\hline 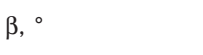 & 90 & $117.54(3)$ & $109.87(3)$ & $98.23(3)$ & $96.94(3)$ & $93.49(3)$ \\
\hline$\gamma, \circ$ & 90 & 90 & 90 & 90 & 90 & 90 \\
\hline$V, \AA^{3}$ & $1151.0(4)$ & $3184.4(11)$ & $3327.4(11)$ & 2833.7(11) & $2505.5(9)$ & $2781.4(10)$ \\
\hline Z & 4 & 4 & 4 & 4 & 4 & 4 \\
\hline Density, $\mathrm{g} \mathrm{cm}^{-3}$ & 1.409 & 1.250 & 1.380 & 1.603 & 1.431 & 1.724 \\
\hline$\mu(\mathrm{MoK} \alpha), \mathrm{mm}^{-1}$ & 0.712 & 0.441 & 0.449 & 0.467 & 0.463 & 0.494 \\
\hline $\mathrm{T}, \mathrm{K}$ & $200(2)$ & $200(2)$ & $200(2)$ & $293(2)$ & $200(2)$ & $200(2)$ \\
\hline $\begin{array}{l}\text { Number of } \\
\text { reflections } \\
\text { (measured) }\end{array}$ & 19200 & 51954 & 11826 & 6858 & 19825 & 22549 \\
\hline $\begin{array}{l}\text { Number of } \\
\text { reflections } \\
\text { (independent) }\end{array}$ & 2650 & 7309 & 6534 & 3589 & 2883 & 3203 \\
\hline $\begin{array}{l}\text { Number of } \\
\text { reflections } \\
\text { (observed) }\end{array}$ & 2447 & 6328 & 4301 & 2692 & 2567 & 2843 \\
\hline $\begin{array}{l}\text { Number of } \\
\text { parameters }\end{array}$ & 145 & 329 & 391 & 403 & 163 & 204 \\
\hline $\mathrm{R} 1(\mathrm{I}>2 \sigma(I))$ & 2.41 & 2.75 & 3.94 & 3.39 & 1.97 & 2.10 \\
\hline wR2 (all data) & 5.55 & 8.13 & 8.49 & 9.20 & 5.46 & 5.63 \\
\hline
\end{tabular}


The structure of the paramagnetic compounds 6 (Fig. 1) and $7^{28}$ show behind the two cyclopentadienyl rings the pyrrolide ligand $\mathrm{N}$-coordinated to the central metal atom. The Ti-N distances [2.090(1) (6) and $2.096(4) / 2.100(3) \AA(7)^{28}$ ] are in the same range as described for Ti amide complexes such as the Ti(IV) bispyrrolide $\mathrm{Cp}_{2} \mathrm{Ti}\left(\mathrm{NC}_{4} \mathrm{H}_{4}\right)_{2}{ }^{19}(\mathrm{Ti}-\mathrm{N} \mathrm{2.070(5)}$, 2.100(4) $\AA$ ) and the Ti(IV) fulvenide pyrrolide [ $\left\{\mathrm{Me} \mathrm{e}_{2} \mathrm{Si}\left(\mathrm{C}_{5} \mathrm{Me}_{4}\right)\right\}\left(\mathrm{C}_{5} \mathrm{Me}_{3} \mathrm{CH}_{2}\right)$ $\left.\mathrm{Ti}\left(\mathrm{NC}_{4} \mathrm{H}_{4}\right)\right]^{20}$ ( $\mathrm{Ti}-\mathrm{N} \mathrm{2.072(4) \AA )}$.

Complexes $\mathbf{9}$ and $\mathbf{1 0}$ are characterized by molecular structural geometry typical for agostic interactions of the alkenyl group $\mathrm{Zr}-\mathrm{C}^{\alpha}=\mathrm{C}^{\beta}-\mathrm{H}$ (Table I). These are $\mathrm{Zr}-\mathrm{C}^{\alpha}$ bonds in the range of a single bond, $\mathrm{C}^{\alpha}-\mathrm{C}^{\beta}$ distances in the range of typical double bonds and a small angle $\mathrm{Zr}-\mathrm{C}^{\alpha}-\mathrm{C}^{\beta}$ which indicates an additional interaction of the $\mathrm{H}\left(C^{\beta}\right)$ with the central zirconium atom (Table I, Figs 2 and 3$)^{31}$.

For structure 12 (Fig. 4), different $\mathrm{Zr}-\mathrm{N}$ distances for the amide ligands (Zr-N1: 2.164(3) $\AA$ or $Z r-N 2: 2.128(4) \AA$ ) were obtained, probably due to weak intermolecular interactions of the fluoro substituents of the benzene rings with hydrogen atoms of the ebthi ligand. The bisanilide 13 (Fig. 5) cannot form such a "network" and exhibits Zr-N distances of 2.1148(11) $\AA$. Comparable $\mathrm{Zr}-\mathrm{N}$ bonds were found in compounds such as $\left(\mathrm{Cp}_{2} \mathrm{Zr}\left(\mathrm{NC}_{4} \mathrm{H}_{4}\right)_{2}\right.$ : $2.171(2) / 2.167(2)^{19}$ and rac-(ebthi) $\left.\mathrm{Zr}\left(\mathrm{HN}-2,6-\mathrm{Me}_{2} \mathrm{C}_{6} \mathrm{H}_{3}\right)_{2}: 2.137(3) \AA{ }^{18}\right)$.

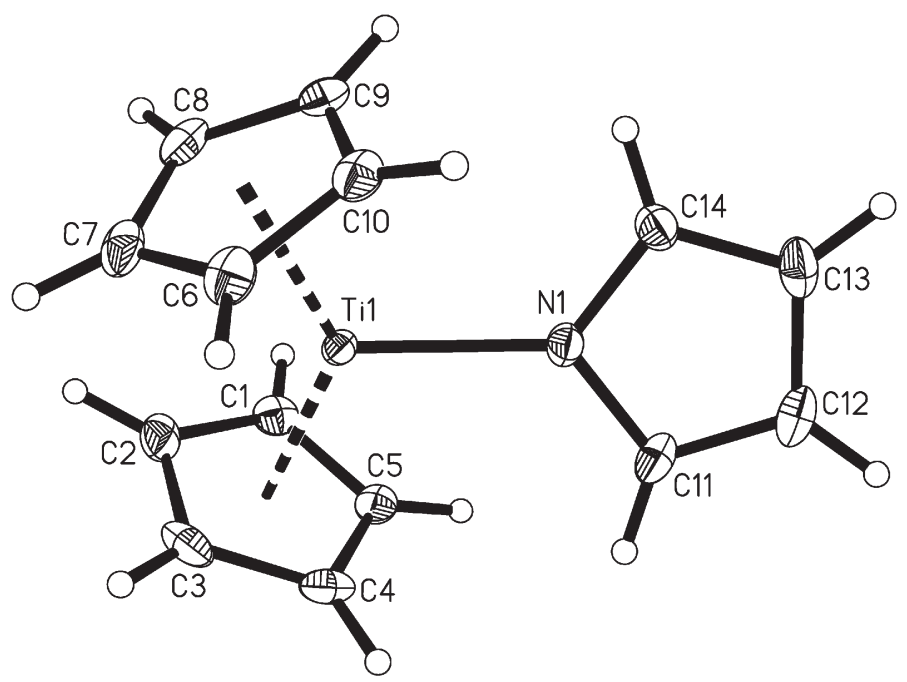

FIG. 1

Molecular structure of complex $\mathbf{6}$ in the crystal. The thermal ellipsoids correspond to $30 \%$ probability 


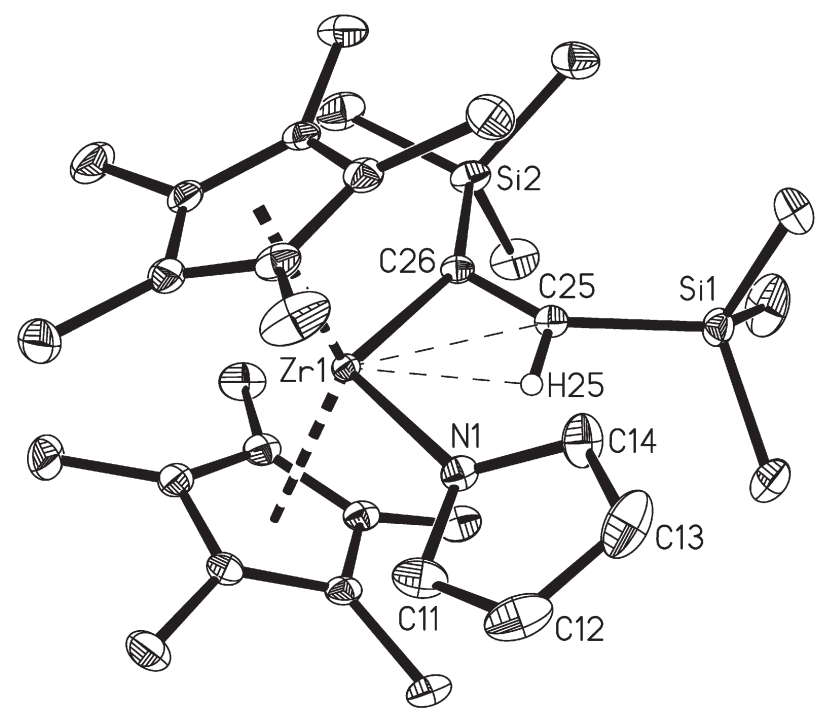

FIG. 2

Molecular structure of complex $\mathbf{9}$ in the crystal. Hydrogen atoms (except H25) are omitted for clarity. The thermal ellipsoids correspond to $30 \%$ probability

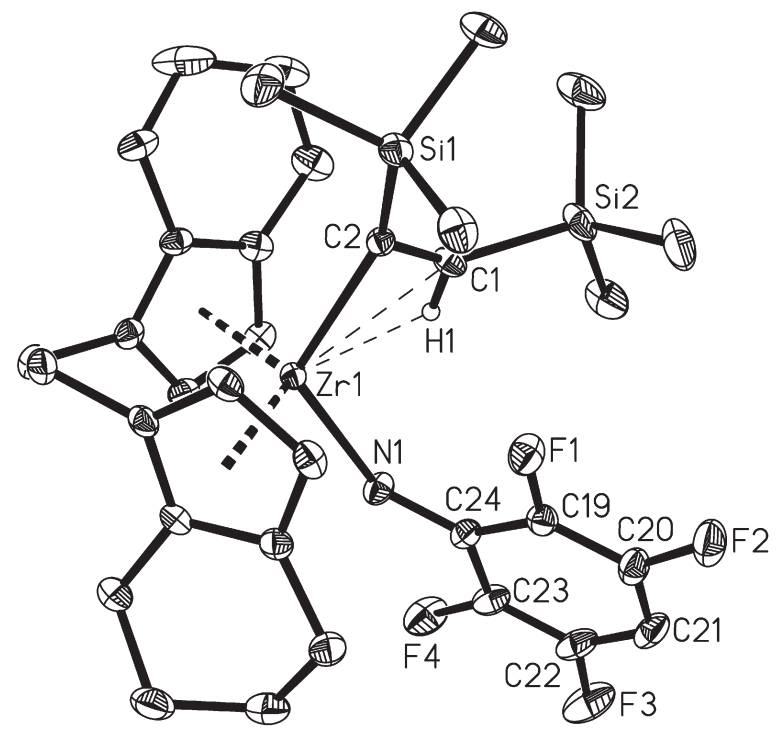

FIG. 3

Molecular structure of complex $\mathbf{1 0}$ in the crystal. Hydrogen atoms (except H1) are omitted for clarity. The thermal ellipsoids correspond to $30 \%$ probability 


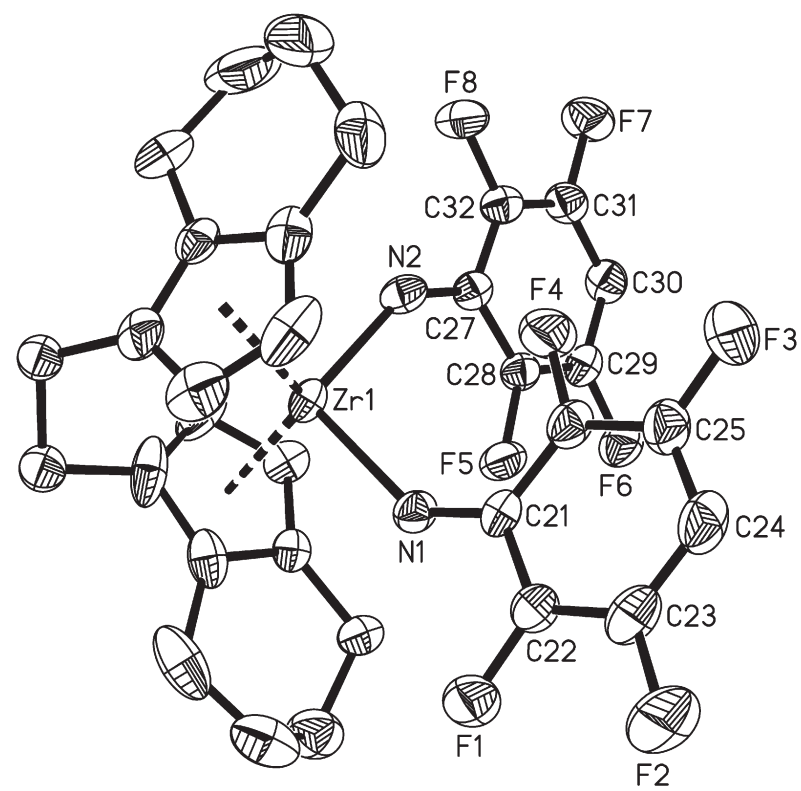

FIG. 4

Molecular structure of complex $\mathbf{1 2}$ in the crystal. Hydrogen atoms are omitted for clarity. The thermal ellipsoids correspond to $30 \%$ probability

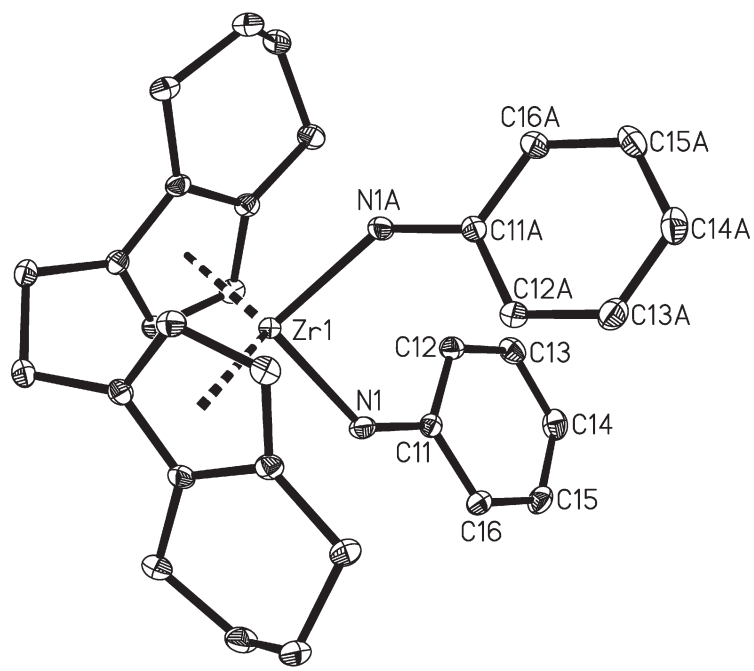

FIG. 5

Molecular structure of complex $\mathbf{1 3}$ in the crystal. Hydrogen atoms are omitted for clarity. The thermal ellipsoids correspond to $30 \%$ probability 
The molecular structure of $\mathbf{1 4}$ (Fig. 6) displays behind the ebthi ligand two equivalent phenolate rings with a $\mathrm{Zr}$-O distance of 2.0334(10) $\AA$ which is slightly elongated in comparison with corresponding bonds in $\mathrm{Cp}_{2} \mathrm{Zr}\left(\mathrm{O}-\mathrm{C}_{6} \mathrm{~F}_{5}\right)_{2}{ }^{29}$ ( $\left.\mathrm{Zr}-\mathrm{O}: 1.991(2) \AA\right)$. The most interesting feature of this structure is the arrangement of $\mathrm{C}_{6} \mathrm{~F}_{5}$ rings. The angle between the plane $\mathrm{O}-\mathrm{Zr}-\mathrm{O} 1 \mathrm{~A}$ and the plane defined by the atoms of the pentafluorophenyl ring amounts to $33.3^{\circ}$ in contrast to compound $\mathrm{Cp}_{2} \mathrm{Zr}\left(\mathrm{O}-\mathrm{C}_{6} \mathrm{~F}_{5}\right)_{2}{ }^{29}$ where this angle is only $9.7^{\circ}$.

The structures of complexes $\mathbf{1 2}$ and $\mathbf{1 4}$ with fluoro-substituted phenyl ligands show no interactions between the fluoro substituents of the aromatic rings and the central atom. This is of interest with regard to catalytic reactions of early transition metal complexes in which such interactions and subsequent $\mathrm{C}-\mathrm{F}$ bond cleavage reactions with the formation of metal fluorides are reported. With this process, deactivation was often discussed. For instance, in the polymerization of ethene by cationic zirconocene complexes a nucleophilic aromatic substitution of $\mathrm{B}\left(\mathrm{C}_{6} \mathrm{~F}_{5}\right)_{3}$ was found ${ }^{34}$. A very low activity was observed in the hydroamination with $\mathrm{Ti}\left(\mathrm{O}-\mathrm{C}_{6} \mathrm{~F}_{5}\right)_{4}$ as a catalyst, compared with other substituted Ti(IV) tetrakisphenolates ${ }^{35}$. Here one could assume an interaction or cleavage of $\mathrm{C}-\mathrm{F}$ bonds as the reason for this

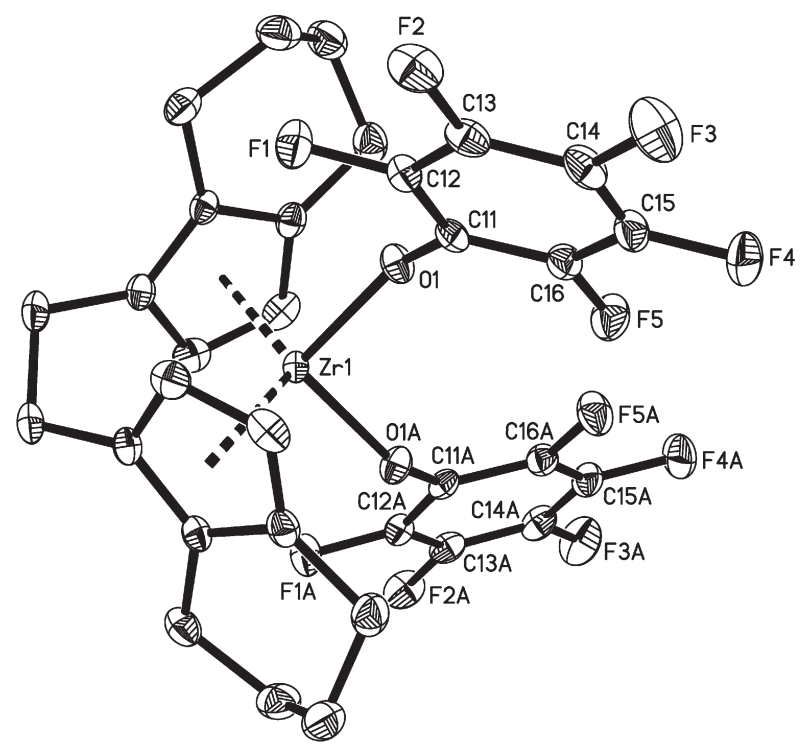

FIG. 6

Molecular structure of complex $\mathbf{1 4}$ in the crystal. Hydrogen atoms are omitted for clarity. The thermal ellipsoids correspond to $30 \%$ probability 
result. Additionally, for the case of $\mathrm{H}_{2} \mathrm{~N}-\mathrm{C}_{6} \mathrm{HF}_{4}$ as a substrate in hydroamination reactions, such interactions must be excluded. From this point of view the structures of compounds $\mathbf{1 2}$ and $\mathbf{1 4}$ are important.

\section{CONCLUSION}

By the reactions presented here, it is well documented that titanocene- and zirconocene-bis(trimethylsilyl)acetylene complexes are able to activate heterocyclic and aromatic $\mathrm{N}-\mathrm{H}$ and $\mathrm{O}-\mathrm{H}$ acid compounds.

Whereas the titanocene-bis(trimethylsilyl)acetylene complexes react with loss of the alkyne and $\mathrm{N}-\mathrm{H}$ bond activation with formation of $\mathrm{Ti}(\mathrm{III})$ monopyrrolide complexes, the corresponding zirconocene systems end up with $\mathrm{Zr}(\mathrm{IV})$ complexes. In a first step, zirconocene complexes with agostic $\sigma$-alkenyl groups are formed by $\mathrm{H}$ transfer from the pyrrole to the alkyne which yield in the second step bisamide complexes under elimination of several silylated compounds, among them the recovered alkyne.

This is a typical different reaction behavior of titanocene- and zirconocenebis(trimethylsilyl)acetylene complexes, affording for titanium, a favored release of the alkyne with the formation of $\mathrm{Ti}(\mathrm{III})$ complexes and, for zirconium, no elimination of the alkyne but the formation of $\mathrm{Zr}(\mathrm{IV})$ complexes. Attempts to obtain an olefin such as $\mathrm{C}_{4} \mathrm{H}_{4} \mathrm{~N}-\mathrm{C}\left(\mathrm{SiMe}_{3}\right)=\mathrm{CH}\left(\mathrm{SiMe}_{3}\right)$ by coupling of the pyrrolide with the alkenyl group have failed so far.

\section{EXPERIMENTAL}

All operations were carried out under argon with standard Schlenk techniques. Prior to use, solvents were freshly distilled from sodium tetraethylaluminate and stored under argon. Deuterated solvents $\left(C_{6} D_{6}\right.$, toluene- $\left.d_{8}\right)$ were treated with sodium or sodium tetraethylaluminate, distilled and stored under argon. Fluorinated pyridines were dried over molecular sieves and degassed before use. The following spectrometers were used: MS: AMD 402; NMR: Bruker AV 300 and Bruker AV 400. Chemical shifts $(\delta, \mathrm{ppm})$ were referenced to signals of the used solvents: $C_{6} D_{6}\left(\delta_{H} 7.16, \delta_{C} 128.0\right)$, toluene- $d_{8}\left(\delta_{H} 2.03, \delta_{C} 20.4\right)$. The ${ }^{19} F$ NMR spectra were referenced externally to $\mathrm{CFCl}_{3}$. The spectra were assigned using DEPT experiments. Melting points: sealed capillaries, Büchi 535 apparatus. Elemental analyses: Leco CHNS-932 elemental analyzer.

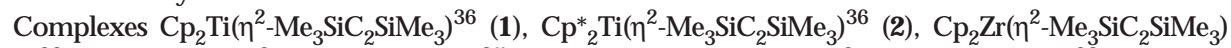
$(\text { thf })^{30}$ (3), Cp* ${ }_{2} \mathrm{Zr}\left(\eta^{2}-\mathrm{Me}_{3} \mathrm{SiC}_{2} \mathrm{SiMe}_{3}\right)^{37}$ (4) and rac- $\left[\mathrm{Zr}(\mathrm{ebthi})\left(\eta^{2}-\mathrm{Me}_{3} \mathrm{SiC}_{2} \mathrm{SiMe}_{3}\right)\right]^{38}$ (5) were prepared by the literature methods.

$$
\left[\mathrm{Cp}_{2} \mathrm{Ti}\left(\mathrm{NC}_{4} \mathrm{H}_{4}\right)\right](6)
$$

To a solution of $\mathrm{Cp}_{2} \mathrm{Ti}\left(\eta^{2}-\mathrm{Me}_{3} \mathrm{SiC}_{2} \mathrm{SiMe}_{3}\right)(\mathbf{1} ; 1.260 \mathrm{~g}, 3.61 \mathrm{mmol})$ in $10 \mathrm{ml}$ of hexane was added pyrrole $(0.50 \mathrm{ml}, 7.21 \mathrm{mmol})$. Within a few minutes the solution slightly darkened and crystals were formed at the bottom and on walls of the reaction tube. After 1 day the 
crystals were separated from the mother liquor by decanting, washed with cooled hexane, and dried in vacuum to give $0.833 \mathrm{~g}(94.3 \%)$ of complex 6, m.p. $170-172{ }^{\circ} \mathrm{C}$. For $\mathrm{C}_{14} \mathrm{H}_{14} \mathrm{NTi}$ (244.1) calculated: $68.88 \%$ C, $5.78 \% \mathrm{H}, 5.74 \% \mathrm{~N}$; found: $68.52 \% \mathrm{C}, 5.45 \% \mathrm{H}, 5.37 \% \mathrm{~N}$.

\section{$\left[\mathrm{Cp}_{2} \mathrm{Zr}\left(\mathrm{NC}_{4} \mathrm{H}_{4}\right)\left\{\mathrm{C}\left(\mathrm{SiMe}_{3}\right)=\mathrm{CH}\left(\mathrm{SiMe}_{3}\right)\right\}\right](\mathbf{8})$}

Complex $\left[\mathrm{Cp}_{2} \mathrm{Zr}\left(\eta^{2}-\mathrm{Me}_{3} \mathrm{SiC}_{2} \mathrm{SiMe}_{3}\right)(\mathrm{thf})\right](3 ; 1.083 \mathrm{~g}, 2.33 \mathrm{mmol}$ ) was dissolved in pyrrole $(2.0 \mathrm{ml}, 28.8 \mathrm{mmol})$. The color instantly turned to light yellow. After $5 \mathrm{~min}$ the mixture was evaporated in vacuum and the residue was dissolved in $15-20 \mathrm{ml}$ of toluene. From the filtered solution a light yellow solid precipitated after 1 day at $-78{ }^{\circ} \mathrm{C}$ which was separated from the mother liquor by decanting, washed with cooled toluene, and dried in vacuum to give $0.790 \mathrm{~g}(73.8 \%)$ of 8 , m.p. $126-127{ }^{\circ} \mathrm{C}$ (dec.). ${ }^{1} \mathrm{H} N M R\left(300 \mathrm{MHz}, \mathrm{C}_{6} \mathrm{D}_{6}, 297 \mathrm{~K}\right): 0.20 \mathrm{~s}$, $9 \mathrm{H}\left(\beta-\mathrm{SiMe}_{3}\right) ; 0.23 \mathrm{~s}, 9 \mathrm{H}\left(\alpha-\mathrm{SiMe}_{3}\right) ; 5.49 \mathrm{~s}, 10 \mathrm{H}(\mathrm{Cp}) ; 6.82$ "t", $2 \mathrm{H}$ ( $\beta$-pyrrolide); 6.91 "t", $2 \mathrm{H}$ ( $\alpha$-pyrrolide); $8.04 \mathrm{~s}, 1 \mathrm{H}\left(=\mathrm{CH}^{\beta}\right) .{ }^{13} \mathrm{C}\left\{{ }^{1} \mathrm{H}\right\} \mathrm{NMR}\left(75 \mathrm{MHz}, \mathrm{C}_{6} \mathrm{D}_{6}, 297 \mathrm{~K}\right): 0.6\left(\beta-\mathrm{SiMe}_{3}\right)$; $2.0\left(\alpha-\mathrm{SiMe}_{3}\right) ; 105.4, \mathrm{~J}_{\mathrm{C}, \mathrm{H}}=100\left(=\mathrm{CH}^{\beta}\right) ; 110.1$ (Cp); 110.1 ( $\beta$-pyrrolide); 132.3 ( $\alpha$-pyrrolide); $232.9(\mathrm{Zr}-\mathrm{C}=\mathrm{C}) .{ }^{29} \mathrm{Si} \mathrm{NMR}\left(79 \mathrm{MHz}, \mathrm{C}_{6} \mathrm{D}_{6}, 297 \mathrm{~K}\right):-9.0,{ }^{3} \mathrm{~J}_{\mathrm{Si}, \mathrm{H}}=19.8,{ }^{2} \mathrm{~J}_{\mathrm{Si}, \mathrm{H}}=6.4\left(\alpha-\mathrm{SiMe}_{3}\right)$; $-5.5,{ }^{2} \mathrm{~J}_{\mathrm{Si}, \mathrm{H}}=6.6 / 3.0\left(\beta-\mathrm{SiMe}_{3}\right)$. For $\mathrm{C}_{22} \mathrm{H}_{33} \mathrm{NSi}_{2} \mathrm{Zr}(458.9)$ calculated: $57.58 \% \mathrm{C}, 7.25 \% \mathrm{H}$, $3.05 \% \mathrm{~N}$; found: $57.36 \% \mathrm{C}, 7.01 \% \mathrm{H}, 2.98 \% \mathrm{~N}$.

\section{$\left[\mathrm{Cp}_{2}{ }_{2} \mathrm{Zr}\left(\mathrm{NC}_{4} \mathrm{H}_{4}\right)\left\{\mathrm{C}\left(\mathrm{SiMe}_{3}\right)=\mathrm{CH}\left(\mathrm{SiMe}_{3}\right)\right\}\right](9)$}

Complex [Cp* $\left.{ }_{2} \mathrm{Zr}\left(\eta^{2}-\mathrm{Me}_{3} \mathrm{SiC}_{2} \mathrm{SiMe}_{3}\right)(\mathrm{thf})\right](\mathbf{4} ; 0.545 \mathrm{~g}, 1.02 \mathrm{mmol})$ was dissolved in $5 \mathrm{ml}$ of toluene and pyrrole was added $(0.20 \mathrm{ml}, 2.88 \mathrm{mmol})$. After 2 days the light yellow solution was evaporated in vacuum and the residue was dissolved in $30 \mathrm{ml}$ of warm hexane $\left(55^{\circ} \mathrm{C}\right)$. The solution was filtered and allowed to stand at $-78{ }^{\circ} \mathrm{C}$. After 1 day light yellow crystals were formed which were separated from the mother liquor by decanting, washed with cooled hexane, and dried in vacuum to give $0.378 \mathrm{~g}(61.6 \%)$ of 9, m.p. $249-250{ }^{\circ} \mathrm{C}$ (dec.). ${ }^{1} \mathrm{H}$ NMR $\left(400 \mathrm{MHz}\right.$, toluene-d $\left.\mathrm{d}_{8}, 297 \mathrm{~K}\right): 0.35 \mathrm{~s}, 9 \mathrm{H}\left(\beta-\mathrm{SiMe}_{3}\right) ; 0.44 \mathrm{~s}, 9 \mathrm{H}\left(\alpha-\mathrm{SiMe}_{3}\right) ; 1.55 \mathrm{~s}$, $30 \mathrm{H}\left(\mathrm{C}_{5} \mathrm{Me}_{5}\right) ; 6.50,6.652 \times \mathrm{br}, 2 \times 1 \mathrm{H}$ ( $\beta$-pyrrolide); $6.67 \mathrm{~s}, 1 \mathrm{H}\left(=\mathrm{CH}^{\beta}\right) ; 6.70,6.812 \times \mathrm{br}, 2 \times$ $1 \mathrm{H}$ ( $\alpha$-pyrrolide). ${ }^{1} \mathrm{H}$ NMR $\left(400 \mathrm{MHz}\right.$, toluene- $\mathrm{d}_{8}, 357 \mathrm{~K}$, the compound starts decomposing!): $0.34 \mathrm{~s}, 9 \mathrm{H}\left(\beta-\mathrm{SiMe}_{3}\right) ; 0.43 \mathrm{~s}, 9 \mathrm{H}\left(\alpha-\mathrm{SiMe}_{3}\right) ; 1.57 \mathrm{~s}, 30 \mathrm{H}\left(\mathrm{C}_{5} \mathrm{Me}_{5}\right) ; 6.38$ "t", $2 \mathrm{H}$ ( $\beta$-pyrrolide); 6.69 "t", $2 \mathrm{H}$ ( $\alpha$-pyrrolide); $6.69 \mathrm{~s}, 1 \mathrm{H}\left(=\mathrm{CH}^{\beta}\right) .{ }^{13} \mathrm{C}\left\{{ }^{1} \mathrm{H}\right\} \mathrm{NMR}(100 \mathrm{MHz}$,

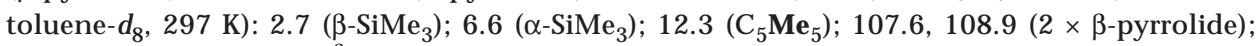
112.8, $\mathrm{J}_{\mathrm{C}, \mathrm{H}}=101\left(=\mathrm{CH}^{\beta}\right) ; 119.2\left(\mathbf{C}_{5} \mathrm{Me}_{5}\right) ; 132.1,133.0(2 \times \alpha$-pyrrolide); $230.6(\mathrm{Zr}-\mathrm{C}=\mathrm{C})$. ${ }^{29} \mathrm{Si} \mathrm{NMR}\left(79 \mathrm{MHz}\right.$, toluene-d $\left.\mathrm{d}_{8}, 297 \mathrm{~K}\right):-9.4,{ }^{3} \mathrm{~J}_{\mathrm{Si}, \mathrm{H}}=21.3,{ }^{2} \mathrm{~J}_{\mathrm{Si}, \mathrm{H}}=6.2\left(\alpha-\mathrm{SiMe}_{3}\right) ;-5.8,{ }^{2} \mathrm{~J}_{\mathrm{Si}, \mathrm{H}}=$ 6.5/3.8 ( $\left(\beta-\mathrm{SiMe}_{3}\right)$. MS (70 eV, m/z): $462\left[\mathrm{Cp}_{2}{ }_{2} \mathrm{Zr}\left(\mathrm{C}_{4} \mathrm{H}_{5} \mathrm{~N}\right)\right]^{+}$. For $\mathrm{C}_{32} \mathrm{H}_{53} \mathrm{NSi}_{2} \mathrm{Zr}(597.3)$ calculated: $64.15 \% \mathrm{C}, 8.92 \% \mathrm{H}, 2.34 \% \mathrm{~N}$; found: $63.95 \% \mathrm{C}, 9.25 \% \mathrm{H}, 2.45 \% \mathrm{~N}$.

\section{[rac- $\left[\mathrm{Zr}\left(\right.\right.$ ebthi) $\left.\left(\mathrm{NH}-\mathrm{C}_{6} \mathrm{HF}_{4}\right)\left\{\mathrm{C}\left(\mathrm{SiMe}_{3}\right)=\mathrm{CH}\left(\mathrm{SiMe}_{3}\right)\right\}\right](\mathbf{1 0})$}

Complex rac-[Zr(ebthi) $\left.\left(\eta^{2}-\mathrm{Me}_{3} \mathrm{SiC}_{2} \mathrm{SiMe}_{3}\right)\right](\mathbf{5} ; 0.300 \mathrm{~g}, 0.57 \mathrm{mmol})$ and 2,3,5,6-tetrafluoroaniline $(0.113 \mathrm{~g}, 0.68 \mathrm{mmol})$ were dissolved in $10 \mathrm{ml}$ of hexane and stirred at room temperature. The color of the solution changed and after two hours the formation of orange crystals started. The orange crystals were separated from the mother liquor, washed with hexane and dried in vacuo. Yield $118 \mathrm{mg}$ (30\%) of 10, m.p. $105{ }^{\circ} \mathrm{C}$ (dec.). ${ }^{1} \mathrm{H}$ NMR $\left(400 \mathrm{MHz}, \mathrm{C}_{6} \mathrm{D}_{6}, 297 \mathrm{~K}\right): 0.18 \mathrm{~s}, 9 \mathrm{H}\left(\mathrm{SiMe}_{3}\right) ; 0.42 \mathrm{~s}, 9 \mathrm{H}\left(\mathrm{SiMe}_{3}\right) ; 1.0-1.8,8 \mathrm{H}\left(\mathrm{ebthi}^{-\mathrm{CH}_{2}}\right)$; 1.9-2.8, $12 \mathrm{H}$ (ebthi- $\mathrm{CH}_{2}$ ); $3.83 \mathrm{br}, 1 \mathrm{H}(\mathrm{NH}) ; 5.17 \mathrm{~d}, 1 \mathrm{H},{ }^{3} \mathrm{~J}_{\mathrm{H}, \mathrm{H}}=2.9$ (ebthi-CH); $5.41 \mathrm{~d}, 1 \mathrm{H}$, $3_{\mathrm{H}, \mathrm{H}}=2.9$ (ebthi-CH); $5.60 \mathrm{~m}, 1 \mathrm{H}$ (ebthi-CH); $5.84 \mathrm{tt}, 1 \mathrm{H}, \mathrm{J}_{\mathrm{F}, \mathrm{H}}=10.3 / 6.9$ (aniline-CH); 
$6.34 \mathrm{~d}, 1 \mathrm{H},{ }^{3} \mathrm{~J}_{\mathrm{H}, \mathrm{H}}=2.6$ (ebthi-CH); $7.20 \mathrm{t}, 1 \mathrm{H}, \mathrm{J}_{\mathrm{F}, \mathrm{H}}=1.8\left(=\mathrm{CH}^{\beta}\right) .{ }^{13} \mathrm{C}\left\{{ }^{\mathrm{H}} \mathrm{H}\right\} \mathrm{NMR}(100 \mathrm{MHz}$, $\left.\mathrm{C}_{6} \mathrm{D}_{6}, 297 \mathrm{~K}\right): 0.8\left(\mathrm{SiMe}_{3}\right) ; 3.6\left(\mathrm{SiMe}_{3}\right) ; 21.4,22.5,22.6,22.9,23.7,23.9,24.8$ (2 C); 28.0, $28.9\left(10 \times\right.$ ebthi- $\left.\mathrm{CH}_{2}\right) ; 86.0 \mathrm{t}, \mathrm{J}_{\mathrm{C}, \mathrm{F}}=24$ (aniline- $\left.\mathrm{CH}\right) ; 102.7,105.8,106.4,110.0(4 \times$ ebthi-CH); 123.1, ${ }^{1} \mathrm{~J}_{\mathrm{C}, \mathrm{H}}=105.1, \mathrm{~J}_{\mathrm{C}, \mathrm{F}}=2.4\left(=\mathrm{CH}^{\beta}\right) ; 118.3,118.4,126.1,127.4,130.1,134.8$ $(6 \times$ ebthi-C); 227.0 ( $\mathrm{Zr}-\mathrm{C}=\mathrm{C})$ ); CF were not detected. ${ }^{19} \mathrm{~F} \mathrm{NMR}\left(282 \mathrm{MHz}, \mathrm{C}_{6} \mathrm{D}_{6}, 297 \mathrm{~K}\right)$ : -143.4 (CF); -160.7 (CF). MS (70 eV, m/z): $518\left(\mathrm{M}^{+}-\mathrm{Me}_{3} \mathrm{SiC}_{2} \mathrm{SiMe}_{3}\right)$. For $\mathrm{C}_{34} \mathrm{H}_{45} \mathrm{~F}_{4} \mathrm{NSi}_{2} \mathrm{Zr}$ (691.1) calculated: $59.09 \% \mathrm{C}, 6.56 \% \mathrm{H}, 2.03 \% \mathrm{~N}$; found: $58.93 \% \mathrm{C}, 6.45 \% \mathrm{H}, 2.01 \% \mathrm{~N}$.

\section{$\left[\mathrm{Cp}_{2} \mathrm{Zr}\left(\mathrm{NC}_{4} \mathrm{H}_{4}\right)_{2}\right](\mathbf{1 1})$}

To complex $\left[\mathrm{Cp}_{2} \mathrm{Zr}\left(\eta^{2}-\mathrm{Me}_{3} \mathrm{SiC}_{2} \mathrm{SiMe}_{3}\right)(\mathrm{thf})\right](3 ; 0.735 \mathrm{~g}, 1.58 \mathrm{mmol})$ was added pyrrole $(2.5 \mathrm{ml}, 36.0 \mathrm{mmol})$ and the mixture was stirred at $90{ }^{\circ} \mathrm{C}$ for 1 day. The resulting yelloworange solution was evaporated in vacuum to dryness. The residue was dissolved in $10-15 \mathrm{ml}$ of toluene giving a yellow solution, which was filtered and allowed to stand at $-30{ }^{\circ} \mathrm{C}$. After 3 days yellow crystals were separated from the mother liquor by decanting, washed with cooled toluene, and dried in vacuum to give $0.373 \mathrm{~g}(66.6 \%)$ of $\mathbf{1 1}, \mathrm{m} . \mathrm{p} .178-180{ }^{\circ} \mathrm{C}$. ${ }^{1} \mathrm{H}$ NMR (300 MHz, $\left.\mathrm{C}_{6} \mathrm{D}_{6}\right)$ : $5.72 \mathrm{~s}, 10 \mathrm{H}(\mathrm{Cp}) ; 6.52$ "tt", $4 \mathrm{H}$ ( $\beta$-pyrrolide); 6.64 "t", $4 \mathrm{H}$ ( $\alpha$-pyrrolide). ${ }^{13} \mathrm{C}\left\{{ }^{1} \mathrm{H}\right\}$ NMR (75 M Hz, $\mathrm{C}_{6} \mathrm{D}_{6}, 297 \mathrm{~K}$ ): $114.2(\mathrm{Cp}) ; 110.1,129.2$ ( $\beta$ - and $\alpha$-pyrrolide). For $\mathrm{C}_{18} \mathrm{H}_{18} \mathrm{~N}_{2} \mathrm{Zr}$ (353.5) calculated: $61.15 \% \mathrm{C}, 5.13 \% \mathrm{H}, 7.92 \% \mathrm{~N}$; found: $61.07 \% \mathrm{C}, 4.98 \% \mathrm{H}, 7.53 \% \mathrm{~N}$.

Formation in the NMR tube: $\left[\mathrm{Cp}_{2} \mathrm{Zr}\left(\mathrm{NC}_{4} \mathrm{H}_{4}\right)\left\{\mathrm{C}\left(\mathrm{SiMe}_{3}\right)=\mathrm{CH}\left(\mathrm{SiMe}_{3}\right)\right\}\right]$ (8; $150 \mathrm{mg}$, $0.328 \mathrm{mmol}$ ) was dissolved in $0.5 \mathrm{ml}$ of $\mathrm{C}_{6} \mathrm{D}_{6}$ and heated to $50^{\circ} \mathrm{C}$. The color of the solution gradually turned to deep green during $6 \mathrm{~h}$ and a mixture of the bisamide $\mathbf{1 1}$ together with free bis(trimethylsilyl)acetylene and further silyl species was observed by NMR monitoring. Almost half of the silyl intensity was found in the free alkyne $\left(\delta\left({ }^{1} \mathrm{H}\right) 0.16, \delta\left({ }^{13} \mathrm{C}\right)-0.1, \delta\left({ }^{29} \mathrm{Si}\right)\right.$ -19.4), a further large amount in a species characterized by $\delta\left({ }^{1} \mathrm{H}\right) 0.11$ and $6.80, \delta\left({ }^{13} \mathrm{C}\right)-1.5$ and $151.1, \delta\left({ }^{29} \mathrm{Si}\right)-7.9$. This might be $(\mathrm{E})-\mathrm{Me}_{3} \mathrm{SiCH}=\mathrm{CHSiMe} \mathrm{e}_{3}$, reference data ${ }^{39}:{ }^{1} \mathrm{H}\left(\mathrm{CDCl}_{3}\right)$ 0.06 and $6.56,{ }^{13} \mathrm{C}\left(\mathrm{CDCl}_{3}\right)-1.2$ and $150.7,{ }^{29} \mathrm{Si}$ (neat) -8.9 . Some more signals were growing in the spectra, but a loss of overall intensity in the $\mathrm{Cp}$ and pyrrole region indicated that unobservable compounds may be generated. Free hydrogen (expected at about $4.5 \mathrm{ppm}$ ) was not found.

\section{rac-[Zr(ebthi) $\left.\left(\mathrm{NH}-\mathrm{C}_{6} \mathrm{HF}_{4}\right)_{2}\right](\mathbf{1 2})$}

The complex rac-[Zr(ebthi) $\left.\left(\eta^{2}-\mathrm{Me}_{3} \mathrm{SiC}_{2} \mathrm{SiMe} \mathrm{M}_{3}\right)\right]$ (5) $(0.300 \mathrm{~g}, 0.57 \mathrm{mmol})$ and 2,3,5,6-tetrafluoroaniline $(0.226 \mathrm{~g}, 1.37 \mathrm{mmol})$ were dissolved in $10 \mathrm{ml}$ of hexane and stirred at room temperature. The color of the solution changed and after a few hours crystallization started. Yellow crystals were separated from the mother liquor, washed with hexane and dried in vacuo. Yield $233 \mathrm{mg}(60 \%)$ of 12, m.p. $220{ }^{\circ} \mathrm{C}$ (dec.). ${ }^{1} \mathrm{H} N M R\left(400 \mathrm{MHz}, \mathrm{C}_{6} \mathrm{D}_{6}, 297 \mathrm{~K}\right.$ ): $1.37 \mathrm{~m}, 4 \mathrm{H}, 1.70 \mathrm{~m}, 4 \mathrm{H}, 2.30 \mathrm{~m}, 6 \mathrm{H}, 2.66 \mathrm{dt}, 2 \mathrm{H}$ (all ebthi- $\mathrm{CH}_{2}$ ); $2.48 \mathrm{AA}^{\prime} \mathrm{BB}^{\prime}, 4 \mathrm{H}$ (ebthi-ethylene); $5.14 \mathrm{~d}, 2 \mathrm{H},{ }^{3} \mathrm{~J}_{\mathrm{H}, \mathrm{H}}=3.2($ ebthi-CH); $5.35 \mathrm{~s}, 2 \mathrm{H}(\mathrm{NH}) ; 5.83 \mathrm{~m}, 2 \mathrm{H}$ (ebthi-CH); $5.96 \mathrm{tt}, 2 \mathrm{H}, \mathrm{J}_{\mathrm{F}, \mathrm{H}}=10.2 / 7.1$ (aniline-CH). ${ }^{13} \mathrm{C}\{\mathrm{H}\} \mathrm{HMR}\left(100 \mathrm{MHz}, \mathrm{C}_{6} \mathrm{D}_{6}, 297 \mathrm{~K}\right)$ : 22.6, 22.7, 23.2, 23.9, $27.4\left(5 \times\right.$ ebthi- $\left.\mathrm{CH}_{2}\right) ; 91.7 \mathrm{t}, \mathrm{J}_{\mathrm{C}, \mathrm{F}}=24$ (aniline-CH); 106.1, $112.4(2 \times$ ebthi-CH); 122.1, 130.9, 131.2 ( $3 \times$ ebthi-C); $138.2 \mathrm{~m}(\mathrm{NH}-\mathrm{C}) ; 138.7 \mathrm{~m},{ }^{1} \mathrm{~J}_{\mathrm{C}, \mathrm{F}}=235 ; 147.0 \mathrm{~m}$, ${ }^{1} J_{C, F}=243(2 \times C F) .{ }^{19} \mathrm{~F} \mathrm{NMR}\left(282 \mathrm{MHz}, \mathrm{C}_{6} \mathrm{D}_{6}, 297 \mathrm{~K}\right):-142.4$ (CF); -156.8 (CF). MS (70 eV, $\mathrm{m} / \mathrm{z}): 354\left(\mathrm{M}^{+}-2 \mathrm{NH}-\mathrm{C}_{6} \mathrm{~F}_{4}\right)$. For $\mathrm{C}_{32} \mathrm{H}_{28} \mathrm{~F}_{8} \mathrm{~N}_{2} \mathrm{Zr}(683.8)$ calculated: $56.20 \% \mathrm{C}, 4.12 \% \mathrm{H}, 4.09 \% \mathrm{~N}$; found: $56.46 \% \mathrm{C}, 4.51 \% \mathrm{H}, 3.81 \% \mathrm{~N}$. 
rac-[Zr(ebthi) $\left.\left(\mathrm{NH}-\mathrm{C}_{6} \mathrm{H}_{5}\right)_{2}\right](\mathbf{1 3})$

The complex rac- $\left[\mathrm{Zr}\left(\right.\right.$ ebthi) $\left.\left(\eta^{2}-\mathrm{Me}_{3} \mathrm{SiC}_{2} \mathrm{SiMe}_{3}\right)\right](5 ; 0.400 \mathrm{~g}, 0.76 \mathrm{mmol})$ was dissolved in $10 \mathrm{ml}$ of hexane and aniline was added $(0.140 \mathrm{ml}, 1.5 \mathrm{mmol})$. The color of the solution changed and yellow crystals of $\mathbf{1 3}$ were immediately formed, which were separated from the mother liquor by decanting. Yield $302 \mathrm{mg}$ (74\%) of 13, m.p. $243{ }^{\circ} \mathrm{C}$ (dec.). ${ }^{1} \mathrm{H} \mathrm{NMR}\left(\mathrm{C}_{6} \mathrm{D}_{6}, 297 \mathrm{~K}\right)$ : 1.3-2.9 m, $20 \mathrm{H}\left(\right.$ ebthi- $\left.\mathrm{CH}_{2}\right) ; 5.07 \mathrm{~d}, 2 \mathrm{H},{ }^{3} \mathrm{~J}_{\mathrm{HH}}=2.9$ (ebthi-CH); $5.86 \mathrm{~d}, 2 \mathrm{H},{ }^{3} \mathrm{~J}_{\mathrm{HH}}=2.9$ (ebthi-CH); $5.96 \mathrm{~s}, 2 \mathrm{H}(\mathrm{NH}) ; 6.75 \mathrm{~m}, 2 \mathrm{H}\left(\mathrm{p}-\mathrm{CH}_{\text {aniline }}\right) ; 6.84 \mathrm{~m}, 4 \mathrm{H}\left(\mathrm{o}-\mathrm{CH}_{\text {aniline }}\right) ; 7.16 \mathrm{~m}, 4 \mathrm{H}$ $\left(\mathrm{m}-\mathrm{CH}_{\text {aniline }}\right) .{ }^{13} \mathrm{C}\left\{{ }^{1} \mathrm{H}\right\} \mathrm{NMR}\left(\mathrm{C}_{6} \mathrm{D}_{6}, 297 \mathrm{~K}\right): 23.2,23.3,23.6,24.2,27.4\left(5 \times \mathrm{CH}_{2}\right) ; 103.8$, 110.3 ( $2 \times$ ebthi-CH); 119.4, 128.7, 129.4 (3 × ebthi-C); 117.8, 118.6, 128.9, 156.4 (4 $\times$ aniline). MS (70 eV, m/z): $355\left(\mathrm{M}^{+}-2 \mathrm{NH}-\mathrm{C}_{6} \mathrm{H}_{5}\right)$. For $\mathrm{C}_{32} \mathrm{H}_{36} \mathrm{~N}_{2} \mathrm{Zr}(538.2)$ calculated: $71.19 \% \mathrm{C}$, $6.72 \% \mathrm{H}, 5.19 \% \mathrm{~N}$; found: $71.12 \% \mathrm{C}, 6.66 \% \mathrm{H}, 4.99 \% \mathrm{~N}$.

\section{$\operatorname{rac}-\left[\mathrm{Zr}(\right.$ ebthi $\left.)\left(\mathrm{OC}_{6} \mathrm{~F}_{5}\right)_{2}\right](\mathbf{1 4})$}

To a solution of rac- $\left[\mathrm{Zr}(\right.$ ebthi $\left.)\left(\eta^{2}-\mathrm{Me}_{3} \mathrm{SiC}_{2} \mathrm{SiMe}_{3}\right)\right](5 ; 0.250 \mathrm{~g}, 0.475 \mathrm{mmol})$ in $15 \mathrm{ml}$ of THF was added pentafluorophenol $(0.175 \mathrm{~g}, 0.951 \mathrm{mmol})$ in $5 \mathrm{ml}$ of diethyl ether under stirring. After $24 \mathrm{~h}$ the yellow solution was evaporated to dryness and the residue was dissolved in hexane. The solution was filtered and reduced in vacuum. At room temperature colorless crystals of 14 were formed. Yield $122 \mathrm{mg}(36 \%)$ of 14, m.p. $132-134{ }^{\circ} \mathrm{C} .{ }^{1} \mathrm{H}$ NMR $(300 \mathrm{MHz}$, $\mathrm{C}_{6} \mathrm{D}_{6}, 298 \mathrm{~K}$ ): $1.30 \mathrm{~m}, 4 \mathrm{H}, 1.50 \mathrm{~m}, 4 \mathrm{H}, 2.21 \mathrm{~m}, 4 \mathrm{H}, 2.43 \mathrm{~m}, 4 \mathrm{H}$ (all ebthi- $\mathrm{CH}_{2}$ ); $2.69 \mathrm{AA}^{\prime} \mathrm{BB}^{\prime}, 4 \mathrm{H}$ (ebthi-ethylene); $5.51 \mathrm{~d}, 2 \mathrm{H},{ }^{3} \mathrm{~J}=3$ (ebthi-CH); $5.75 \mathrm{~d}, 2 \mathrm{H},{ }^{3} \mathrm{~J}=3$ (ebthi-CH). ${ }^{13} \mathrm{C}\left\{{ }^{1} \mathrm{H}\right\}$ NMR $\left(75 \mathrm{MHz} \mathrm{C}_{6} \mathrm{D}_{6}, 298 \mathrm{~K}\right): 22.2,22.6,23.4,23.5\left(4 \times\right.$ ebthi-CH$\left.{ }_{2}\right) ; 28.0$ (ebthi-ethylene); 108.2, 114.8 (2 × ebthi-CH); 123.1, 133.2, 133.9 (3 × ebthi-C); CF not detected. ${ }^{19} \mathrm{~F}$ NMR (282 M Hz, C $\left.6 \mathrm{D}_{6}, 298 \mathrm{~K}\right):-162.3 \mathrm{~m}, 4 \mathrm{~F} ;-165.5 \mathrm{~m}, 4 \mathrm{~F} ;-172.1 \mathrm{tt}, 2 \mathrm{~F}$ (para). MS (70 eV, m/z): $720\left(\mathrm{M}^{+}\right), 537\left(\mathrm{M}^{+}-\mathrm{OC}_{6} \mathrm{~F}_{5}\right)$. For $\mathrm{C}_{32} \mathrm{H}_{24} \mathrm{~F}_{10} \mathrm{O}_{2} \mathrm{Zr}(721.7): 53.25 \% \mathrm{C}, 3.35 \% \mathrm{H}$; found: $52.86 \%$ C, $3.19 \% \mathrm{H}$.

\section{X-ray Crystallography}

Data were collected with a STOE-IPDS-diffractometer using graphite-monochromatized $\mathrm{MoK} \alpha$ radiation. The structures were solved by direct methods (SHELXS97) ${ }^{40}$ and refined by full-matrix least-squares techniques against $F^{2}(S H E L X L 97)^{41}$. XP (Bruker AXS) was used for structure representations.

CCDC 634160 (for 6), 634161 (for 9), 634162 (for 10), 634163 (for 12), 634164 (for 13), 634165 (for 14) contain the supplementary crystallographic data for this paper. These data can be obtained free of charge via www.ccdc.cam.ac.uk/conts/retrieving.html (or from the Cambridge Crystallographic Data Centre, 12, Union Road, Cambridge, CB2 1EZ, UK; fax: +44 1223 336033; or deposit@ccdc.cam.ac.uk).

This work was supported by the Deutsche Forschungsgemeinschaft (SPP 1118, Project No. Ro 1269/6), the Land Mecklenburg-Vorpommern and the Russian Foundation for Basic Research (Project No. 02-03-32589). Funding and facilities provided by the Leibniz-Institut für Katalyse e. V. an der Universität Rostock are gratefully acknowledged. 


\section{REFERENCES AND NOTES}

1. Ohff A., Pulst S., Lefeber C., Peulecke N., Arndt P., Burlakov V. V., Rosenthal U.: Synlett 1996, 111.

2. Rosenthal U., Pellny P.-M., Kirchbauer F. G., Burlakov V. V.: Acc. Chem. Res. 2000, 33, 119.

3. Rosenthal U., Burlakov V. V. in: Titanium and Zirconium in Organic Synthesis (I. Marek, Ed.), Chap. 10, p. 350. Wiley-VCH, Weinheim 2002.

4. Rosenthal U., Burlakov V. V., Arndt P., Baumann W., Spannenberg A.: Organometallics 2003, 22, 884 .

5. Rosenthal U., Arndt P., Baumann W., Burlakov V. V., Spannenberg A.: J. Organomet. Chem. 2003, 670, 84.

6. Rosenthal U.: Angew. Chem. 2003, 115, 1838; Angew. Chem., Int. Ed. 2003, 42, 1794.

7. Spannenberg A., Arndt P., Baumann W., Rosenthal U.: J. Organomet. Chem. 2003, 683, 261.

8. Rosenthal U.: Angew. Chem. 2004, 116, 3972; Angew. Chem., Int. Ed. 2004, 43, 3882.

9. Spannenberg A., Arndt P., Baumann W., Rosenthal U.: J. Organomet. Chem. 2003, 683, 261.

10. Rosenthal U. in: Acetylene Chemistry II. Chemistry, Biology, and Material Science (F. Diederich, P. J. Stang and R. R. Tykwinski, Eds), p. 139. Wiley-VCH, Weinheim 2003.

11. Kraft S., Beckhaus R., Haase D., Saak W.: Angew. Chem. 2004, 116, 1609; Angew. Chem., Int. Ed. 2004, 43, 1583.

12. Piglosiewicz I. M: M.S. Thesis. University of Oldenburg, Oldenburg 2004.

13. Piglosiewicz I. M., Kraft S., Beckhaus R., Haase D., Saak W.: Eur. J. Inorg. Chem. 2005, 938.

14. Kraft S., Hanuschek E., Beckhaus R., Haase D., Saak W.: Chem. Eur. J. 2005, 11, 969.

15. Piglosiewicz I. M., Beckhaus R., Saak W., Haase D.: J. Am. Chem. Soc. 2005, 127, 14190.

16. Issleib K., Bätz G.: Z. Anorg. Allg. Chem. 1969, 369, 83.

17. Walsh P. J., Baranger A. M., Bergman R. G.: J. Am. Chem. Soc. 1992, 114, 1708; and references therein.

18. Wartchow R., Doye S. L.: J. Organomet. Chem. 1998, 566, 287.

19. Vann Bynum R., Hunter W. E., Roger R. D., Atwood J. L.: Inorg. Chem. 1980, 19, 2368.

20. Lee H., Bonnno J. B., Bridgewater B. M., Churchill D. G., Parkin G.: Polyhedron 2005, 24, 1356.

21. Feldman J., Calabrese J. C.: J. Chem. Soc., Chem. Commun. 1991, 1042.

22. Blum S. A., Walsh P. J., Bergman R. G: J. Am. Chem. Soc. 2003, 125, 14276; and references therein.

23. a) Fairfax D., Stein M., Livinghouse T., Jensen M.: Organometallics 1997, 16, 1523;

b) McGrane P. L., Livinghouse T.: J. Org. Chem. 1992, 57, 1323.

24. Beller M., Seayad J., Tillack A., Jiao H.: Angew. Chem. 2004, 116, 3448; Angew. Chem., Int. Ed. 2004, 43, 3368.

25. a) Lefeber C., Arndt P., Tillack A., Baumann W., Kempe R., Burlakov V. V., Rosenthal U.: Organometallics 1995, 14, 3090; b) Arndt P., Lefeber C., Kempe R., Rosenthal U.: Chem. Ber. 1996, 129, 207; c) Tillack A., Arndt P., Spannenberg A., Kempe R., Rosenthal U.: Z. Anorg. Allg. Chem. 1998, 624, 737. 
26. a) Witte P. T., Klein R., Koojman H., Spek A. L., Polášek M., Varga V., Mach K.: J. Organomet. Chem. 1996, 519, 195; b) Gyepes R., Witte P. T., Horáček M., Císařová I., Mach K.: J. Organomet. Chem. 1998, 551, 207.

27. Rep M., Kaagman J.-W. F., Elsevier C. J., Sedmera P., Hiller J., Thewalt U., Horáček M., Mach K.: J. Organomet. Chem. 2000, 597, 146.

28. Spannenberg A., Burlakov V. V., Arndt P., Klahn M., Rosenthal U.: Z. Kristallogr. 2007, submitted; two molecules in the asymmetric unit.

29. Amor J. I., Burton N. C., Cuenca T., Gómez-Sal P., Royo P.: J. Organomet. Chem. 1995, $485,153$.

30. Rosenthal U., Ohff A., Michalik M., Görls H., Burlakov V. V., Shur V. B.: Angew. Chem. 1993, 105, 1228; Angew. Chem., Int. Ed. Engl. 1993, 32, 1193.

31. Horáček M., Štěpnička P., Kubišta J., Gyepes R., Mach K.: Organometallics 2004, 23, 3388.

32. Arndt P., Lefeber C., Tillack A., Rosenthal U.: Chem Ber. 1996, 129, 1281.

33. Arndt P., Baumann W., Spannenberg A., Rosenthal U., Burlakov V. V., Shur V. B.: Angew. Chem. 2003, 115, 1455; Angew. Chem., Int. Ed. 2003, 42, 1414.

34. Arndt P., Jäger-Fiedler U., Klahn M., Baumann W., Spannenberg A., Burlakov V. V., Rosenthal U.: Angew. Chem. 2006, 118, 4301; Angew. Chem., Int. Ed. 2006, 45, 4195.

35. Tillack A., Khedkar V., Jiao H., Beller M.: Eur. J. Org. Chem. 2005, 5001.

36. Burlakov V. V., Polyakov A. V., Yanovsky A. I., Struchkov Y. T., Shur V. B., Volpin M. E., Rosenthal U., Görls H.: J. Organomet. Chem. 1994, 476, 197.

37. Hiller J., Thewalt U., Polášek M., Petrusová L., Varga V., Sedmera P., Mach K.: Organometallics 1996, 15, 3752.

38. Lefeber C., Baumann W., Tillack A., Kempe R., Görls H., Rosenthal U.: Organometallics 1996, $15,3486$.

39. a) Marciniec B., Pietraszuk C., Foltynowicz Z.: J. Organomet. Chem. 1994, 474, 83; b) Lippmaa E., Mägi M., Chvalovský V., Schraml J.: Collect. Czech. Chem. Commun. 1977, $42,318$.

40. Sheldrick G. M.: SHELXS97, Program of Crystal Structure Solution. University of Göttingen, Göttingen 1997.

41. Sheldrick G. M.: SHELXL97, Program of Crystal Structure Refinement. University of Göttingen, Göttingen 1997. 